\title{
Hahnemann's Achievements and Modern Medicine
}

\author{
Peter Morrell ${ }^{1}$ \\ 1 United Kingdom \\ Homœopathic Links 2016;29(1):6-8.
}

Address for correspondence Peter Morrell, 12 Burton Court, Burton Square, ST17 9LU, United Kingdom (e-mail: petermrrll@yahoo.co.uk).
Abstract
Keywords
- Hahnemann
- energy
- achievements
- allopathy
- palliation

This essay gives a brief outline of Hahnemann's energy, achievements and publications with a brief comparison of homeopathy to modern medicine.
For anyone involved in homeopathy, it is useful from time to time to reflect on the life and achievements of Hahnemann. And we do this not to eulogise or worship him, but to see his creation, homeopathy, in the context of the modern medical world with all its emphasis on genetics and microbiology. Hahnemann's work and ideas are much more relevant in the modern world than one might suppose.

When we look at his life and achievements, two key features of Hahnemann tend to stand out clear. He worked tirelessly and entirely alone to find the truth in medicine. Both in his researches and in his experiments, he allowed nothing to distract him from his life's mission. He never stopped 'drilling down' through centuries of falsehoods, errors and illusions until he hit the firm bedrock of truth. And it is abundantly clear also that all the time in doing this-and unlike all his contemporaries-his eyes were wide open and free from biasing theories or preconceptions. He has been portrayed by some medical historians as a theorist and by allopaths as a mere system builder, and that homeopathy is just a theory. These portrayals could not remain far from the truth. Even though he was clothed more than most physicians of his day with a very clear grasp of all the theories and ideas of medical history, his outlook was always entirely open, fresh and empirical. Nothing impressed him more than what he could see with his own eyes and touch with his own fingers; theories per se hardly ever came into the picture. Homeopathy is primarily and fundamentally a practical method, not a theory.

In surveying his life and all his endeavours this way, he also clearly impresses us as a man of indefatigable energy and creativity. One will actually labour hard to find a comparable figure in the entire history of medicine. Nobody in medical history comes even close to the sheer scale of his endeavours, his detailed comprehension of every aspect of medicine and pharmacy, the depth, breadth and precision of his learning, his voluminous published output and the ceaseless energy of his experimentation. Very few come close to him on even one of these aspects of the man, let alone coming close to all of them! It is no exaggeration to say that he stands out across the entire length of medical history as a colossus, a courageous pioneer, a fearless groundbreaker, an innovator in every aspect of medical theory and practice and, of course a rebel, a troublemaker. And he remorselessly slayed falsehoods wherever he found them. ${ }^{\mathrm{a}, 1}$

He also seems never to have rested on his laurels, not even for a second. If we examine his major publishing landmarks quite aside from his 21 large textbook translations, even though he had published the Fragmenta and the Medicine of Experience (both in 1805), then the Organon, he then published the six volumes of Materia Medica Pura and the two volumes of Chronic Diseases. Not content even with these impressive achievements, his restless energy then drove him on to update all his writings and to issue new, revised editions every year or two. It is easy to believe that this applies only to the Organon, but it is also true for the Materia Medica Pura and the Chronic Diseases (see - Appendix 1.). He incorporated into each new edition, the latest ideas and methods that had been revealed to him through his researches since the previous edition. This

\footnotetext{
a The 10 volumes of provings he has left us are an eternal monument to his energy, perseverance, conscientiousness, and self-sacrifice. 'When', says he, 'we have to do with an art whose end is the saving of human life, any neglect to make ourselves thoroughly masters of it becomes a crime!' (Dudgeon RE, Lectures on the Theory \& Practice of Homeopathy, London \& Manchester, UK: Henry Turner \& Co; 1853:xlvii.)
}

(C) 2016 Thieme Medical and Scientific Publishers Private Ltd.
DOI http://dx.doi.org/ $10.1055 / \mathrm{s}-0036-1572514$. ISSN 1019-2050. 
way, it is abundantly clear that his achievement is even more massive than it first appears. He truly was a man of ceaseless energy and creativity, and nothing, absolutely nothing, slowed him down or distracted him from the primary mission and purpose of his life. No wonder then the epitaph on his gravenon inutiliz vixi (I have not lived in vain!).

What probably then strikes us most about his life is his bold rejection of all the mainstream medical practices and theories of his day. This means mixed drugs in strong doses, reliance on corrupt drug merchants, using bloodletting and purging, and in due course also the barbaric treatment and locking up in dungeons of the mentally disturbed. Here for once was a man prepared to risk everything by really sticking his neck out and saying fearlessly what was wrong in the medicine of his day and why. He point-blank refused to prostrate himself at the feet of professors or to genuflect to the views and beliefs of revered senior medical practitioners; he boldly dismissed them all as fools, and then spent the rest of his life finding better alternatives to all their outdated and dangerous methods. No wonder then his motto-aud sapere (dare to know!).

When we examine modern homeopathy and compare its findings and ideas with those of modern mainstream medicine, we do this in the same spirit in which Hahnemann himself compared his own ideas, discoveries and methods with those of the medicine of his day. In doing this, we see a medicine focused on its theories and its methods almost solely on attacking bacteria, viruses and genetics. It seems to direct all its vast financial and human resources on these aims. And in these endeavours it works incessantly to do one thing: to create chemical drugs that it thinks will defeat these alleged enemies of humanity.

Modern medicine has become almost solely a drug-based industry. And all this horrifies the average homeopath and most other practitioners of natural medicine too, because we know that most sickness in the world does not come from bacteria, viruses or genetics; rather, it comes from two other sources: lifestyle factors and innate predispositions. ${ }^{\mathrm{b}}$ Neither of these factors are being addressed with anything like the same vigour as the ceaseless attacks on bacteria, viruses and genetics. In other words, they direct their energy, resources and weapons at entirely the wrong targets and virtually ignore the two main causes of sickness in modern societies. Though highly profitable, chemical drugs cannot cure lifestyle disorders and nor can they remove innate predispositions. Therefore, in homeopathic terms, modern medicine is little better than the medicine of Hahnemann's day 200 years ago. It is just as uncurative, palliative and suppressive as it has ever been:

All pure experience, however, and all accurate research convince us that persistent symptoms of disease are far from

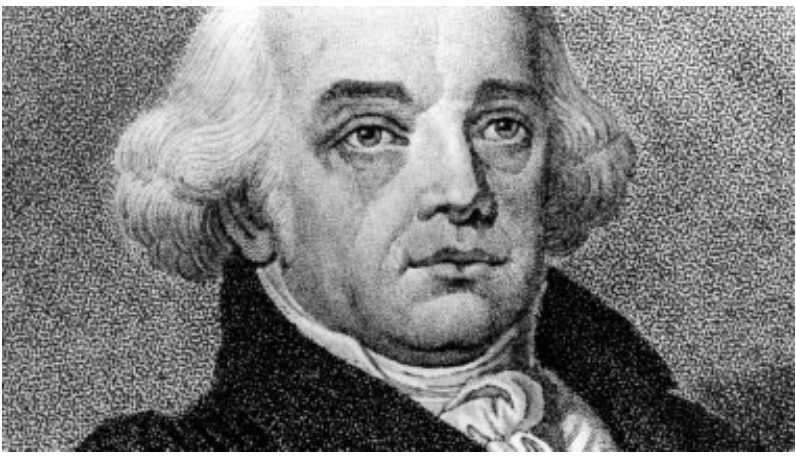

Fig. 1 Samual Hahnemann - holistic before the term was invented.

being removed and annihilated by opposite symptoms of medicines (as in the antipathic, enantiopathic or palliative method), that, on the contrary, after transient, apparent alleviation, they break forth again, only with increased intensity, and become manifestly aggravated. (Organon, §23); He laments 'the inefficacy of the treatment by contraries', (Dudgeon, Lectures, p.49) and alludes to the dangers of using strong antipathic drugs because ‘a stronger dose of the remedy...necessitates giving ever increasing quantities of the palliative', (Organon, §60) but this merely suppresses the sickness, bringing limited and transient relief and comfort to the sick, but never 'a permanent and perfect cure'. (Organon, §61) ${ }^{1}$

As most homeopaths know, clean and pure cases of sickness (e.g., in children) respond swiftly and smoothly to the most similar remedy; quick and easy cases are always those that have never used any allopathic drugs or vaccines; moderately easy cases are those that have used few allopathic drugs in their lifetime; the most difficult cases are always those that have received allopathic drugging repeated many times over many years. In this way, modern cases reveal exactly the same patterns which Hahnemann and the early homeopaths observed and the study of modern cases entirely confirms our beliefs about the nature of suppression, palliation and what true cure means. Modern cases entirely confirm our beliefs about the holistic nature of sickness (symptom totality) and disease as an expression of internal derangements of the life force: of manifest effects and of their hidden causes (-Fig. 1 ).

\section{References}

1 Hahnemann S In: Boericke W, ed, Dudgeon RE, trans. The Organon of Medicine. Combined 5th/6th ed. Philadelphia, PA: Boericke \& Tafel; 1922

\footnotetext{
b Deaths by Cause UK 2011: http://www.theguardian.com/news/ datablog/2012/nov/06/deaths-mortality-rates-cause-death-2011 which shows that at least $70 \%$ of modern mortalities in the United Kingdom are caused by poor lifestyle, which could therefore be avoided by lifestyle improvements and which cannot be cured using drugs. These include most circulatory disorders (strokes and heart disease), most cancers and many nervous, respiratory, endocrine and digestive disorders.
} 


\section{Appendix 1 Publication Dates}

The publication dates of Hahnemann's books on homeopathy (excluding his translations and essays) prove what a very busy man he was:
Organon
1st $=1810$
2nd $=1819$
3rd $=1824$
4 th $=1829$
5 th $=1833$
6 th $=1842$

\section{Materia Medica Pura}

1st edition

The first volume was published in 1811

The second volume was published in 1816

The third volume was published in 1817

The fourth volume was published in 1818

The fifth volume was published in 1819

The sixth volume was published in 1821

The second edition was a revised edition published in six volumes

The first volume was published in 1821

The second volume was published in 1824

The third volume was published in 1825

The fourth volume was published in 1825

The fifth volume was published in 1826

The sixth volume was published in 1827

3rd edition

Vol. I, 1830

Vol. II, 1833

\section{Chronic Diseases}

1st edition of Die Chronischen Krankheiten

It contained four volumes

The first three volumes were published in 1828

The fourth volume was published in 1830

2nd edition of Die Chronischen Krankheiten

It contained five volumes

The first two volumes were published in 1835

The third volume was published in 1837

The fourth volume in 1838

The fifth volume was published in 1839 